\title{
A FEW AND MISCELLANEOUS PI-CHI JOTTINGS ON EARLY INDONESIA
}

\author{
O. W. Wolters
}

Those interested in "Sriwijayan" studies know that inscriptions and a diverse range of archaeological materials have now taken precedence over Chinese documents as research tools. The pilgrim 1-ching's writings, the chapters on foreign countries in the Chinese dynastic histories, and Chao Ju-kua's Chu-fan chih were translated as long ago as the second half of the nineteenth and early years of the twentieth centuries, and since then nothing of comparable importance has come to light in Chinese sources. " The participants in the SPAFA-sponsored "Sriwijayan Project" have properly recommended that what has already been translated needs to be catalogued, verified, and reconsidered alongside other sources of information, especially archaeological evidence now being unearthed in southeastern Sumatra and peninsular Thailand. ${ }^{2}$ Current field research is gradually shifting the discussion from the shopworn topic of the location of Sriwijaya's capital to the substance of Sriwijayan history, which is the geomorphological environment and political systems of early Malay culture.

Nevertheless, the hope that new Chinese materials will be discovered should not be extinguished. The translated sources represent only a tiny fraction of Chinese writings. An immense number of "notebooks," or miscellaneous works ( $p_{i-c h i),}$ amounting, perhaps, to hundreds of volumes, remains to be explored. ${ }^{3}$ The $p i-c h i$

1. I wish to thank E. Edwards McKinnon for his helpful suggestions. For a sketch of Sriwijayan historiography, see O. W. Wolters, "Studying Sriwijaya," Journal of the Malaysian Branch of the Royal A siatic Society [hereafter JMBRAS], 52, 2 (1979), pp. 1-14.

2. "SPAFA" represents the Seameo Project in Archaeology and Fine Arts. SPAFA's "Sriwijaya Project" is being vigorously undertaken. See SPAFA Digest [published by the SPAFA Co-ordinating Unit, Bangkok], 3, 2 (1982) for papers presented to, and a description of, field research during the work shop held in southeastern Sumatra from August 31 to September 11, 1982. Also see The History and Archaeology of Śrivijaya. Papers from the 1982 Surat Thani Seminar, Archaeological Division, Fine Arts Department, Bangkok, November 1982; "Introduction and English Abstracts" are on pp. 221-33. Recent ceramic evidence is summarized in E. Edwards McKinnon and Bernadien Sinta Dermawan, "Further Ceramic Discoveries at Sumatran Sites," Transactions No. 8 of the Southeast Asian Ceramic Society (Singapore, 1981), pp. 2-17.

3. Pi-chi are discussed in Herbert Franke, "Some Aspects of Chinese Private Historiography in the Thirteenth and Fourteenth Centuries, " in Historians of China and Japan, ed. W. G. Beasley and E. G. Pulleyblank (London: Oxford University Press, 1961), pp. 115-34. Also see Colin Mackerras, "Unofficial Regional Records," in Essays on the Sources for Chinese History, ed. Donald D. Leslie et al. (Canberra: Australian National University Press, 1973), pp. 75-82; Endymion Wilkinson, The History of Imperial China. A Research Guide, Harvard East Asian Monographs 49, 
have been described as comprising "very uneven jottings on a huge range of subjects," and those who read them are advised that "it is often surprising what these works contain." 4 Always written and collected by scholars for scholars, their contents were often intended to supplement the official histories. On the other hand, they sometimes recorded amusing anecdotes or ghost stories, and were frequently written simply to provide entertainment. ${ }^{5}$

Chou Ch'ü-fei's Ling-wai tai-ta, written in 1178, and Chao Ju-kua's Chu-fan chih, written in 1225, are unusually valuable and well-known contributions of this genre to Southeast Asian studies, ${ }^{6}$ but with the great majority of pi-chi, information which will engage the attention of those who are not historians of China is embedded amid a mass of entries. Only sinologists are likely to consult the pi-chi, and they cannot be expected to recognize and communicate to historians of Southeast Asia the materials of benefit to them. Yet the situation is not hopeless. Gu Hai, who teaches early Southeast Asian history in the Xia-men University, Fujian, and who spent the academic year of 1982-83 at Cornell University as a Visiting Fellow, tells me that he proposes to prepare a bibliographical survey of materials in pi-chi literature to assist in the study of Southeast Asian history. His project, though bound to be time consuming, offers the hope that Chinese writings will continue to supply useful and, maybe, important data.

Gu Hai suggested that I should glance at a few specimens, especially those of the Sung (960-1279) period, and keep my eyes open for materials relating to early Indonesian history. ${ }^{7}$ During the Sung period trade between China and Southeast Asia became increasingly brisk. A recent study, amply documented from pi-chi sources, shows that what was originally an import trade in a limited number of luxury goods had by then proliferated and permeated much of Chinese society. ${ }^{8}$ One important reason was that Chinese merchant ships were regularly visiting Southeast Asian centers of production, a trend that became pronounced after the capture of northern China by the Chin in 1127. This background suggests that pi-chi of these centuries are likely to include a few glimpses of Indonesia.

East Asian Research Center, Harvard University (Cambridge, Mass., 1974), pp. 173-75; Wolfgang Franke, An Introduction to the Sources of Ming History (Kuala Lumpur: University of Malaya Press, 1968), pp. 98-100.

4. Wilkinson, History of Imperial China, p. 173.

5. See Franke, "Some Aspects of Chinese Private Historiography," p. 116, for Yu-tang's characterization of the pi-chi and for Franke's observations.

6. For a German translation of Chou Ch'ü-fei's Ling-wai tai-ta, see Almut Netolitzky, Das Ling-wai tai-ta von Chou Ch'ü fei [Münchener Ostasiatische Studien, Band 21] (Wiesbaden: Steiner, 1977); and for an English translation of Chao Ju-kua's Chufan chih see Friedrich Hirth and W. W. Rockhill, Chau Ju-kua (St. Petersburg: Imperial Academy of Sciences, 1911).

7. I am grateful to $\mathrm{Gu} \mathrm{Hai}$ for his suggestion and thank him for discussing these jottings with me.

8. Grace Wong, "Origin, Diffusion, and Assimilation of Selected Products of the Southeast Asian World into Chinese Cultural Life" (MA thesis, National University of Singapore, 1982). The expansion in maritime trade between 960 and 1159 is reflected in Sung revenue, which increased from 300,000 strings of cash to 2,000,000. The revenue from maritime trade in the 1128-1159 period was nearly twice what had been collected in the 1102-1111 period; see Paul Wheatley, "Geographical Notes on Some Commodities Involved in Sung Maritime Trade, " JMBRAS, 32, 2 (1959), p. 24. 
In this article I shall consider some jottings in the pi-chi collections which Gu Hai brought to my notice, and I shall also mention a few relevant entries in the massive Sung hui-yao chi-kao $[S H Y C K] .{ }^{9}$ I have consulted a total of seven pi-chi. My single T'ang author is Su 0 , who lived in the second half of the ninth century. Respected in later times for his elegant literary style, he collected and recorded interesting episodes of the 763-873 period and sometimes described precious tributary gifts brought to China by foreign envoys. Five of my pi-chi were compiled in Sung times. They are, in the sequence in which they will be mentioned: Chu Yü's $P^{\prime}$ ing-chou k'o-t'an (1118-1119), Chou Ch'ü-fei's Ling-wai tai-ta (1178), Hung Mai (1123-1202)'s /-chien chih, P'ang Yüan-ying's Wên-ch'ang tsa-lu (based on materials collected in 1082-1088), and Chao Yen-wei's Yün-lu man-ch'ao (1206). These authors were officials, but only $\mathrm{Chu} Y \ddot{\mathrm{u}}$ and $\mathrm{Chou} C h$ 'ü-fei had opportunities for recording information about Southeast Asia. Chu Yü, in addition to writing notes on material culture in China, the machinery of government, the lives of prominent people, predictions, and dreams, was able to incorporate evidence provided by his father, Chu $\mathrm{Fu}$, who had served in Canton before being appointed in charge of that city from 1099 to 1102. Chou Ch'ü-fei was an official in southwestern China, and his Ling-wai tai-ta is familiar to Southeast Asian historians on account of the extracts that appear in the footnotes of Hirth and Rockhill's Chau Ju-kua. In the same volume Hirth and Rockhill also translated some of Chu Yü's materials but not the two passages that will concern me. At the time P'ang Yüan-ying was writing he was in charge of the reception of foreign guests in the Northern Sung capital of $\mathrm{K}$ 'ai-fêng and had access to ambassadors. His notes have plenty of information about the Sung court. Chao Yen-wei was a senior official in southeastern China, and most of his entries are concerned with Chinese administration. Hung Mai was a very different pi-chi writer, who chose to assemble an enormous number of tales. $\mathrm{His}$ work has been described as the precursor of "romanesque" literature and a faithful mirror of Sung society in the twelfth century. My last text is Chou Mi's Kuei-hsin tsa-shih (c. 1298), compiled when the author was in retirement in Hangchou after the fall of the Sung. He wrote about famous Sung personalities, contemporary events, and daily life in Hang-chou. ${ }^{10}$

The Sung pi-chi refer to San-fo-ch'i, which I identify with Jambi. I believe that from $1079 \mathrm{Jambi}$, and probably Muara Jambi, was where the overlord of southeastern Sumatra resided. Indeed, thereafter "Sriwijaya" may not be the appropriate name of the overlord's center; epigraphic references to "Sriwijaya" cease with the Cóla inscription of 1030-1031, while the Yüan sources (1260-1368) abandon the name "San-fo-ch'i" in favor of "Malayu" and "Palembang." I understand

9. I have used the facsimile edition of Hsü Sung's recompilation (1809-1810) from the Yung-lo ta-tien, published by the Chung-hua press, Shanghai, 1957. The SHYCK is "the draft of documents pertaining to matters of state in the Sung dynasty"; A Sung Bibliography (initiated by Etienne Balazs and edited by Yves Hervouet) (Hong Kong: Chinese University Press, 1978), pp. 177-78. Also see Ssŭ-yü Teng and Knight Biggerstaff, An Annotated B ibliography of Selected Chinese Reference Works (Cambridge, Mass.: Harvard University Press, 1971), pp. 117-18.

10. For Su O, see the Introduction to Su O (fl. 890), Tu-yang tsa-p'jen, Ts'ungshu chi ch'êng collection (Ch'ang-sha: Shang-wu Press, 1939). Brief accounts of the others are provided in Hervouet, Sung Bibliography. On Chu Yü also see Jitsuzo Kuwabara, "On P'u Shou-keng . . . ." Memoirs of the Research Department of the Toyo Bunko, 2 (1928), p. 69. Kuwabara uses pi-chi literature to advantage. In the relevant footnotes I cite the editions I have used for all my pi-chi writers. 
"Malayu" to mean the polity on the Batang Hari river which was Kertanagara's target in 1275. ${ }^{11}$ Considerable quantities of Sung-Yüan sherds have recently been found in the candi complex at Muara Jambi and also at Muara Kumpeh on the southern coast of the Batang Hari estuary. ${ }^{12}$

I shall begin with two passages in the $P^{\prime} i n g$-chou $k^{\prime} o-t^{\prime} a n$. They concern southeastern Sumatra.

In 1911 Hirth and Rockhill, studying Chao Ju-kua's Chu-fan chih of 1225 , translated excerpts from the $P^{\prime} i n g-c h o u ~ k^{\prime} o-t$ 'an, compiled by Chu Yü probably in 1118-1119. They were interested in information about the conduct of foreign trade in Canton and overseas shipping routes, ${ }^{13}$ and they had no occasion to translate the passages that refer to San-fo-ch'i. The first passage invites us to recall some details about Buddhism in southeastern Sumatra.

In Canton I [Chu Yü] once attended a public feast. ${ }^{14}$ The foreigners assembled in the [government] office. The foreign headman introduced

11. My interpretation of the evidence for the shift of capital is in "A Note on the Capital of Śrivijaya during the Eleventh Century," Essays Offered to G. H. Luce, ed. Ba Shin, Jean Boisselier, A. B. Griswold, 2 vols. (Ascona, Switzerland: Artibus Asiae, 1966), 1, pp. 225-39. I would like to know the significance of the reference in 1082 to "the daughter of the chief official of that country"; ibid., p. 233. References to prominent women in early Southeast Asia often conceal political alliances. For the Yüan toponyms, see 0 . W. Wolters, The Fall of Śrivijaya in Malay History (Ithaca: Cornell University Press, 1970), pp. 46-47. In 1225 Chao Ju-kua described Palembang as a dependency of San-fo-ch'i. Current research in the Muara Jambi area is making it more and more credible that this was the overlord's center in later Sung and in Yüan times. The candi exhibit Singasari-Majapahit art forms, while Sung and Yüan sherds are being found in increasing numbers. The toponym "Sungei Malayu" in the same area may explain why I-ching in the seventh century mentioned as "Malayu" the country on the Sumatran east coast immediately north of Sriwijaya and why the Yüan and Javanese in the thirteenth century referred to "Malayu." Southeast Asian place names have the habit of surviving over many centuries. Even today the people in the lower reaches of the Batang Hari refer to themselves as "orang Melayu."

12. For recent ceramic discoveries at Muara Kumpeh Hilir, about fifty kilometers downstream from Muara Jambi, see E. Edwards McKinnon, "A Brief Note on Muara Kumpeh Hilir: An Early Port Site on the Batang Hari?" SPAFA Digest, 3, 2 (1982), pp. 37-40. The sherds belong approximately to the period from the twelfth to the fourteenth centuries and resemble those found at the late Sung and Yüan trading site of Kota Cina in the Medan area of northeastern Sumatra. Similar sherds have recently been found at Koto Kandis. which is forty kilometers downstream from Muara Kumpeh Hilir and about forty kilometers from the sea. The coastline of the lowest reaches of the Batang Hari in Sung-Yüan times seems to have been more or less where it is today. Recent geomorphological evidence makes it almost certain that neither the Jambi nor the Bukit Seguntang polities were "coastal" ones in the strict sense of the term. For a recent clarification of the Musi estuary in earlier times, see P. $-Y$. Manguin, "Sumatran Coastline in the Straits of Bangka: New Evidence for Its Permanence in Historical Times"; ibid., pp. 24-28 and p. 49.

13. Hirth and Rockhill, Chau Ju-kua, pp. 20-21; p. 23, nn. 1 and 2; p. 31, n. 2; p. $64, \mathrm{n} .7$.

14. I have followed Kuwabara, "On P'u Shou-keng," p. 43, in translating K'ao-shê as "public feast." The local authorities gave the feast for returning foreign traders. 
someone from San-fo-ch'i and said that he could recite the K'ung-ch'üeh [ "Peacock"] ming-wang sūtra. My view is that Buddhist works which [contain] dhärani [magical formulae] are incomprehensible. I supposed that he was not telling the truth and was glad to get proof. I therefore asked him to recite. He put his hands behind his back, leaned on a pillar, and cried aloud. The noise resembled that of boiling water being poured into a vase [a sizzling noise?]. Surely there was no sound like this in the "Peacock" sūtra's dhărani handed down over the generations. I said that the book had already been translated [from Sanskrit into Chinese] and could not be the same [as the one being recited]. The practice [in China] has been to offer recitations of this sūtra to the dead. I do not know how a Chinese soul could understand [what I had just heard]. ${ }^{15}$

The sūtra in question is the Mahāmāyūri vidyārajint sūtra, one of the Paficarakșā ("Quintuple Protection") sūtras and a famous one among Buddhists of the tantrayāna persuasion. ${ }^{16}$ The sūtra honors a powerful spiritual force represented as a peacock and offers its devotees many talismanic formulae (dhäraṇi $)$ for protection against dangers. Some of its contents are as old as Buddhism itself and are in the Pali canon. A Sanskrit version existed at least as early as the fourth century $A D$, when it was first translated into Chinese. ${ }^{17}$ A monk from southern Cambodia translated it into Chinese in the early sixth century, and 1-ching, who worked in Sriwijaya in the second half of the seventh century and recommended that Chinese pilgrims should study Sanskrit there, also translated the sūtra. Amoghavajra, leader of the tantric sect in China in the middle of the eighth century, revised Iching's translation and, in 746 , chanted it during a rain-making ceremony in China. ${ }^{18}$ The tantrayāna had been introduced to China by Amoghavajra's teacher, Vajrabodhi, who visited Sriwijaya in 717 and may have met the youthful Amoghavajra in Java not long afterwards. 19

1-ching probably brought a copy of the "Peacock" sūtra with him from India, and nothing is known about the sūtra's influence in Sumatra until it is mentioned in the P'ing-chou $k^{\prime} o-t^{\prime} a n$. On the other hand, we know that tantric teachings were already familiar in the Sriwijayan court in the second half of the seventh century. An Old-Malay inscription of 684, found in the neighborhood of Bukit Seguntang, Palembang, reveals that key words in the tantric lexicon were localized, ${ }^{20}$ and OldMalay inscriptions in southern Sumatra of the same period show that magical imprecations were uttered as a means of protection. One inscription, found at Sabokingking, Palembang, reveals that the ruler's enemies as well as the ruler used magical

15. Chu Yü, $P^{\prime}$ ing-chou $k^{\prime} o-t^{\prime} a n$. Ts'ung-shu chi ch'êng collection (Ch'ang-sha: Shang-wu Press, 1939), ch. 2, p. 20.

16. The sūtra is discussed in: Sylvain Lévi, "Le catalogue géographique des Yakșa dans la Mahāmāyūri," Journal asiatique, 11, 5 (1915), pp. 19-138; Chou Yi-liang, "Tantrism in China," Harvard Journal of Asiatic Studies, 8, 3-4 (1945), pp. 241332; André Bareau, "Le Bouddhisme Indien," in Les religions de I'Inde, 3, ed. W. Schubring and $C$. von Fürer-Haimendorf (Paris: Payot, 1966), pp. 203-4. I am grateful to Raoul Birnbaum for discussing the sūtra with me.

17. Chou Yi-liang, "Tantrism in China," p. 324.

18. Ibid., p. 292.

19. For the likelihood that Vajrabodhi also went to Java in 718 and did not reach Canton until 719, see ibid., pp. 321-22.

20. On this point see Petrus Zoetmulder's remarks in Waldemar Stöhr and P. Zoetmulder, Les religions d'Indonésie (Paris: Payot, 1968), pp. 267-68. 
curses. ${ }^{21}$ The ruler did so on the occasion of an oath-taking ceremony; dire consequences were threatened if the oath of allegiance were broken. J. G. de Casparis thinks that this evidence alludes to vaśikarana ceremonies, extensively used in Buddhist tantrism to overpower one's enemies. ${ }^{22^{\circ}}$ In India the "Peacock" sūtra was also invoked at oath-taking ceremonies and in courts of law to make people tell the truth. ${ }^{23}$ The inscription goes on to show that spiritual rewards were offered to the ruler's loyal followers, and the ruler promised to reward them with tanträmala ("immaculate as a consequence of Tantra"). De Casparis suggests that the ruler was offering amulets or charms with magical formulae inscribed on them. ${ }^{24}$ In India formulae from the "Quintuple Protection" sūtras were also used on protective amulets.

None of this evidence suggests that the "Peacock" sūtra had been localized in southern Sumatra by the end of the seventh century, but the practice of invoking magical sanctions recommended in the sūtra would certainly have made sense to Malays at that time. The "Peacock" sūtra contains numerous appeals to local tutelary spirits, ${ }^{25}$ while the first lines of two of the Old-Malay inscriptions, written in a so-far unidentified Austronesian language, seem to include an appeal by the Sriwijayan ruler to "the spirits of the waters." 26 Perhaps the special language of the first lines was used to strengthen the effect of the appeal and had the same function of conveying an aura of "authoritativeness" that quotations in Sanskrit had in Old-Javanese parwa literature. ${ }^{27}$

The "Peacock" sūtra, an armory of magical formulae, would sooner or later have become a congenial text in southeastern Sumatra, and the reference to it in the $P^{\prime}$ ing-chou $k^{\prime} o-t^{\prime} a n$ is not at all surprising. Sriwijaya continued to belong to the world of tantric Buddhism long after the seventh century, as impressive evidence from Tibetan sources illustrates. Early in the eleventh century Atîsa, the tantric missionary to Tibet, studied in Sriwijaya under the famous teacher, Dharmakirti. ${ }^{28}$ Alex Wayman wonders whether Atísa had picked up tantric works during his student days at Sriwijaya. ${ }^{29}$ All we know from Chinese sources, however, is that Palembang,

21. J. G. de Casparis, Prasasti Indonesia // (Bandung: Masa Baru, 1956), pp. 15-46.

22. Ibid., p. 30 .

23. Information provided by Raoul Birnbaum.

24. De Casparis, Prasasti Indonesia II, p. 31 and n. 55.

25. See Lévi, "Le catalogue géographique," pp. 30-57. Mus, commenting on Lévi's study of the yakșa in the Mahāmāyūri, stresses the "singular favour" which enumerations of local spirits, protectors of a kingdom or town, have enjoyed in Buddhist texts; Paul Mus, "Barabuḍur . . . cinquième partie," Bulletin d'École française $d^{\prime}$ Extrême-Orient (hereaftèr BEFEO), 33, $2(1933), p .668, n$. 4. The remains of Candi Angsoka can still be seen near the center of the city of Palembang. Mckinnon tells me that one Malay meaning of "angsoka" is "the peacock's crest."

26. L. -C. Damais, "Études soumatranaises III. La langue B des inscriptions de Srì Wijaya," BEFEO, 54, (1968), pp. 524-66.

27. Petrus J. Zoetmulder, Kalangwan. A Survey of Old Javanese Literature (The Hague: Nijhoff, 1974), p. 92.

28. G. Coèdes, The Indianized States of Southeast Asia, ed. Walter F. Vella and trans. Susan Brown Cowing (Honolulu: East-West Center Press, 1968), Pp. 143-44.

29. Alex Wayman, "Reflections on the Theory of Barabudur as a Mandala," in Barabudur. History and Significance of a Buddhist Monument, ed. Luis 0 . Gómez 
the seat of the Malay overlords until the second half of the eleventh century, continued to be on the pilgrim route between China and India in early Sung times. According to the Sung hui-yao chi-kao, in 983 the Chinese monk, Fa-yü, returning from India, met the Indian monk, Mi-mo-lo-shih-li, in San-fo-ch'i and advised him to petition the emperor for permission to go to China and translate sütras. On another occasion Fa-yü wanted to visit India and asked the emperor to give him letters of introduction to the rulers of $S a n-f o-c h^{\prime} i, K o-k u-l o$, and other countries. ${ }^{30}$ The same source states that in 986 the Chinese monk, P'ei-hsien, studied the Sinhalese, Jurchen, San-fo-ch'i, and Javanese scripts. ${ }^{31}$ The Sung-shih supplies an additional detail about Sriwijaya's Buddhist associations. In 1017 the ruler presented the Sung emperor with sūtras written on palm leaf. ${ }^{32}$

Art historians are probably best qualified to contribute to the study of tantric influence in Sumatra. Much more needs to be known before the context for Chu Yü's random jotting about the "Peacock" sūtra becomes clearer. Enough is known, however, to make the jotting credible. The Malay from San-fo-ch'i is likely to have recited in Sanskrit because of the magical sound of its words. Chu Yü, familiar with a Chinese translation of the sūtra, naturally thought he was listening to gibberish.

The other passage in the $P^{\prime} j i n g-c h o u k^{\prime} o-t^{\prime} a n$ is an account of San-fo-ch'i towards the end of the eleventh century, when, $I$ believe, the ruler lived in the Jambi area and probably at Muara Jambi. The passage concerns the familiar entrepôt of "Sriwijayan" history. Hirth and Rockhill translated the two sentences in brackets.

Every country in the southern ocean has its chief. San-fo-ch'i is invariably described as a great country. [lt possesses its own script and merchants say that the people there can calculate future eclipses of the sun and moon. But the Chinese cannot understand the script. $]^{33}$ The land has a great deal of sandalwood and frankincense, and these products are [Chinese] trade goods. San-fo-ch'i ships send the frankincense to China, and the [Chinese] Trade Office treats the product as a [government] monopoly and reserves a percentage to sell on its own account. In recent years Sanfo-ch'i has established [its own] monopoly in sandalwood. The ruler orders merchants to sell it to him. The cost of the product [therefore] increases several times. Foreign merchants do not dare to purchase it privately. This is a clever system. The country is exactly [at the center of] the southern ocean. The Ta-shih [Arab] countries are far away to its west. Chinese going to Ta-shih reach San-fo-ch'i, repair their ships, and exchange goods. Merchants from distant places congregate there. This country is therefore considered to be very prosperous. ${ }^{34}$

and Hiram W. Woodward, Jr., Berkeley Buddhist Studies series (Berkeley, Calif.: Lancaster-Miller, 1981), p. 141.

30. SHYCK, fan-i 4, p. 7758. See Paul Wheatley, The Golden Khersonese (Kuala Lumpur: University of Malaya Press, 1961), pp. 59-60, for the identification of $\mathrm{Ko}-\mathrm{ku}-\mathrm{lo}$ somewhere northwest of Mergui.

31. SHYCK, tao-shih 2, p. 7892.

32. Sung-shih (Po-na edition), ch. 489, p. $14 \mathrm{a}$.

33. I have modified the translation of Hirth and Rockhill, Chau Ju-kua, p. 64, n. 7, to read "script" instead of "books."

34. Chu Yü, P'ing-chou k'o-t'an, ch. 2, p. 19. 
The $P^{\prime}$ ing-chou $k^{\prime} O-t^{\prime} a n$ contains the earliest of three accounts of San-fo-ch'i so far known in Sung pi-chi literature. The other two are in Chou Ch'ü-fei's Lingwai tai-ta of $1178^{35}$ and Chao Ju-kua's Chu-fan chih of 1225. Hirth and Rockhill noted passages in Chao Ju-kua's account that drew on Chou Ch'ü-fei's, but they did not compare Chou Ch'ü-fei's description with Chu Yü's, compiled with the assistance of materials available at least three quarters of a century earlier. I shall translate Chou Ch'ü-fei's account and then observe significant differences between what he says and what Chu Yü says.

San-fo-ch'i is on an important thoroughfare in the southern ocean for all foreigners using the maritime route. To the east are Java and other countries. To the west are the Ta-shih [countries], Quilon, and other countries. Traders from all these countries must pass through this area to reach China. The country [of San-fo-ch'i] has no products, but its people are skillful in warfare and attack. They digest medicine in their bodies, and weapons cannot wound them. They attack on land and sea and are foremost in both [forms of warfare]. All the neighboring countries therefore submit [to Sanfo-ch'i]. If foreign ships traveling through this region do not enter the country, [San-fo-ch'i] is bound to send out an expedition to destroy them. The country is therefore rich in rhinoceros [horn], ivory, jewels, and aromatics. The custom in this country is to fasten floating rafts in the water and live on them. Among its dependencies is Fo-lo-an, ${ }^{36}$ whose chief is chosen and appointed by San-fo-ch'i. Fo-lo-an produces incense much more powerful than any incense from the Lower Coast countries. ${ }^{37}$ it is excellent. There is a sacred Buddha image [in San-fo-ch'i], and the ruler visits it every year and burns incense.

Chou Ch'ü-fei's account ends with a list of San-fo-ch'i's missions to China in 960 , $961,962,1079$, and 1088. "The example it set in showing a sense of duty in coming to [ the Chinese] court was unequalled by other countries." 38

More than seventy-five years separate these two accounts, and the situation off the southeastern coast of Sumatra had evidently deteriorated in the meantime. Chu Yü described Jambi as a thriving and peaceful trading center. San-fo-ch'i sent western Asian frankincense to China, and its ruler had "in recent years" expanded his trade to include a monopoly in sandalwood, which is a product of Java and islands in the eastern archipelago. ${ }^{39} \mathrm{Chu} Y \ddot{u}$ did not think it necessary to mention the route from Java to Jambi. San-fo-ch'i, "a great country, " prospered on account of its geographical position and entrepôt function, which attracted merchants from distant lands. Chou Ch'ü-fei's account is very different. San-fo-ch'i had no products of its own and relied on force to compel foreign ships to visit it. The same writer elsewhere observed that, among the wealthy foreign countries with many valuable trade goods, none could compare with the Arab ones; next came Java and then San-fo-ch'i. ${ }^{40}$ We need not doubt that both accounts incorporate the ex-

35. On Chou Ch'ü-fei see Hervouet, Sung Bibliography, pp. 158-59. See also above n. 6 .

36. I follow Wheatley's identification of Fo-lo-an as a possible reference to [Kuala] Berang in Trengganu; Wheatley, Golden Khersonese, p. 70.

37. "The Lower Coast" refers to the Indonesian archipelago; ibid., p. 63.

38. Chou Ch'ü-fei, Ling-wai tai-ta, Ch'in-ting ssü-k'u ch'üan-shu edition (Taipei : Shang-wu press, 1975), ch. 2, pp. 13a-b.

39. See Wheatley, "Geographical Notes on Some Commodities," p. 66, for a map of areas where sandalwood trees grow.

40. Chou Ch'ü-fei, Ling-wai tai-ta, ch. 3, p. 12a. 
perience of Chinese and other merchants familiar with the conditions of overseas trade, and the differences provide convincing evidence that time had not stood still on the southeastern coast of Sumatra.

One reason for the decline in Jambi's entrepôt status in the twelfth century would have been that Chinese ships were sailing regularly to Southeast Asian centers of production in increasing numbers and encouraging non-Chinese traders to visit ports where they could do business with Chinese. A number of rival entrepôts were now flourishing, and Kota Cina on the northeastern coast of Sumatra in the Medan area is now a famous example of this development. By Chou Ch'ü-fei's day Chinese merchants were unlikely to be willing to be hamstrung by the Jambi ruler's monopolist pretensions. Chou's account of San-fo-ch'i makes it clear that "foreign ships," and therefore not Chinese ships, were the ones that faced destruction if they did not sail to Jambi's harbor.

Against this background of changing conditions of foreign trade, the significant detail in the $P^{\prime}$ ing-chou $k^{\prime} o-t^{\prime} a n^{\prime} s$ account of San-fo-ch' $i$ is surely the unambiguous statement that, about 1100 , Chinese shippers were already habitually, though apparently still unprotestingly, sailing to the Arab countries via Jambi and were repairing their ships there. I am unaware of earlier and equally unambiguous information that pinpoints the time when Chinese shippers were frequently sailing to the southern seas and beyond. Han Zhen-hua, of the Southeast Asia Research Institute of $X i a-m e n$ University, tells me that a late tenth century inscription from near Fu-chou in Fujian province was written on behalf of a prominent merchant, Chu Fang, to thank the Buddha for protecting him at sea during his voyage to San-fo-ch'i. The ship in question is not identified, though Han Zhen-hua suspects that it was Chinese. If this is so, such voyages were probably still spasmodic; Chu Fang evidently considered that his voyage was a dangerous enterprise. Paul Wheatley has noted that in 987 and 1028 the Sung government had to persuade foreign traders to visit Chinese ports, ${ }^{41}$ which suggests that the Chinese component in overseas trading ventures was not yet sufficient to maintain the level of trade that the Chinese government required. The so far undocumented period for the expansion of Chinese shipping in the southern ocean seems to be the last three-quarters of the eleventh century.

A more precise dating of the history of Chinese overseas shipping activities will contribute to studies of later Sung and Yüan sherds found in ever-increasing quantities in Southeast Asia. Only Chinese ships could import ceramics on this scale. Similarly, an exact dating of Chinese kilns that specialized in large-scale export ware will help to define the time when Chinese voyages can be presumed to have been frequent enough to carry abroad large quantities of ceramics. ${ }^{42}$ Perhaps

41. Wheatley, "Geographical Notes on Some Commodities," pp. 24-25.

42. Feng Xianming, of Beijing University and a specialist in Chinese kiln sites, has recently suggested somewhat later dates for much of the ceramic material in the Sarawak River delta and Gedong, and his analysis would mean that intensive maritime trade contact between China and this coast began as late as the twelfth century but grew considerably in the thirteenth and fourteenth centuries. Chu Yü knew that Chinese ships were regularly visiting San-fo-ch'i about 1100 , and the following hundred years may therefore be when Chinese voyages to Southeast Asian centers of production were becoming more ubiquitous. For a summary of Feng Xianming's views, see Lucas Chin, "Some Results on SPAFA Regional Seminar-cumWorkshop on Ceramics of East and Southeast Asia and a Tentative Review on the Dating of Trade Ceramics Discovered in Sarawak, "The Sarawak Museum Journal, 34, 50 [new series] (1981), pp. 1-2. The proposed ceramic chronology coincides with the single carbon date from the Sarawak River delta, which is 1315 with a \pm 95 
the relatively small quantity of high quality ceramics of an earlier vintage found in Southeast Asia can be accounted for as imports by non-Chinese ships in the tenth and eleventh centuries and were destined for courts and monasteries.

The expansion of Chinese overseas shipping in the twelfth century would have political consequences in southeastern Sumatra. In earlier centuries foreign trade came to China through the mechanism of the tributary trade system, and no Southeast Asian country prospered more than Sriwijaya. A Japanese scholar, M. Shiraishi, has observed that, whereas in the case of China's neighbors tributary missions were sent when the local or Chinese ruler had died to been succeeded, San-fo-ch'i's missions cannot be explained in this way; according to her, missions from the entrepôt ruler had nothing to do with changes of Chinese or Malay rulers. ${ }^{43}$ The reason can only be that these missions were important commercial occasions. But what were Jambi's missions intended to achieve when China's foreign trade no longer depended on tribute? To suggest an explanation, I shall digress for a moment on the subject of tributary relations under the Sung.

Missions from China's immediate neighbors were no doubt usually sent when there was a change in local or Chinese rulers in order to reaffirm a prudent relationship. But elsewhere in Asia missions were also sent when a "vassal" wanted to establish a favorable status in respect of other rulers whom he knew were Chinese vassals. One advantage was that he was making it known that he acknowledged no overlord other than the emperor; his local status was therefore that of an autonomous ruler who regarded himself as the equal of other Chinese vassals. Special titles, the number of envoys and quantities of tribute permitted to be admitted to China, imperial gifts of clothing and flags, elaborate caskets to enclose the emperor's reply, reception procedures in the Chinese capital, and scale of entertainment, were among the marks of favor at the emperor's disposal. Foreign rulers would be especially anxious for favors that signified their seniority vis-à-vis other Chinese vassals, for the Sung emperors sometimes rewarded faithful "vassals" by promoting them to higher ranks in the Chinese hierarchy of subordinate princes. Distinctions of rank were part of the political culture of Southeast Asia, and special favors conferred by the emperors were valued. Sometimes envoys from two or more countries visited the Chinese capital at the same time and were quick to spot differences in the treatment accorded to foreign envoys. ${ }^{44}$

The Sung records provide instances of how foreign rulers were concerned to be accorded status in the Chinese court. In 1007 envoys sent by the ruler of Butuan in northeastern Mindanao requested the Sung court to give them the same class of flags as those recently given to Cham envoys. ${ }^{5}$ Though they were given presents, their request for the flags was rejected on the ground that "Butuan was beneath Champa." The reason for the discrimination is probably that Butuan had only recently been registered as a Chinese vassal. ${ }^{46}$ The granting of two special privileges

years margin of error; Tom Harrisson and Stanley J. O'Connor, Excavation of the Prehistoric Iron Industry in West Borneo, Data Paper No. 72, 2 vols. (Ithaca: Cornell University Southeast Asia Program, 1969), 1, p. 18.

43. Communication by Tatsuro Yamamoto to the Eighth Conference of the International Association of Historians of Asia, held in Kuala Lumpur, August 1980.

44. A study of Sung protocol for receiving foreign missions would contribute to the history of China's relations with Southeast Asia.

45. SHYCK, fan-i 4, p. 7761. Cham and Butuan envoys were in the Chinese capital between October 17 and November 14, 1004, when flags were presented to the Cham envoys; ibid., pp. 7747 and 7761.

46. The first Butuan mission arrived in 1003 and the final one in 1011. Grace Wong 
of court protocol to the Cōla envoys in 1077 was a recognition of high status in the eyes of the Sung emperor. ${ }^{47}$ In 1015 the Colla ruler had been regarded only as the equal of the Kucha ruler in central Asia. ${ }^{48}$ Nevertheless, in 1106 the Chinese court, apparently responding to the Pagan envoys' complaint that the Chinese were proposing to grant them the same protocol privileges granted to the Colla envoys in 1077, agreed that the Pagan king ruled "a great country" and should not be treated as the equal of the ruler of a small and dependent country. In 1106 the Chinese officials evidently believed that the Cöla ruler was San-fo-ch'i's vassal. The emperor therefore decided that the Pagan envoys should be treated as the equals of the envoys from the Arab countries and Chiao-chih (Vietnam). ${ }^{49}$ In the middle of the twelfth century the Lý ruler of Vietnam, China's immediate neighbor, mounted a number of lavish missions in order to improve his status in the Chinese court, and in 1074 his efforts were rewarded by the bestowal of the title of "king of An-nam."50 The name given to his country had prestige because "An-nam" was the name of the former T'ang province of Vietnam. ${ }^{51}$

In these instances the Sung rulers conferred marks of favor, which their vassals could measure in terms of the status accorded to other vassals. But sometimes recognition by the emperor was sought when a ruler had repudiated a dependent status vis-à-vis his neighbor. Two polities in the lower Chao Phraya basin sent missions during the intervals in the twelfth and early thirteenth centuries when they were free from Khmer overlordship. ${ }^{52}$ The same motive persisted in the second half of the fourteenth century in the early Ming period. Chinese envoys in 1370 persuaded the Brunei ruler to submit to China, and the ruler knew that the implication was that he was ignoring the claims of his Javanese overlord. ${ }^{53}$ In the 1370 s the rulers

is, to the best of my knowledge, the first to suggest that the Chinese transcription "P'u-tuan" should be restored as Butuan; Grace Wong, "The Place of Porcelain," in Chinese Celadons and Other Related Wares in Southeast Asia, compiled by the Southeast Asian Ceramic Society, Singapore (Singapore: Arts Orientalis, 1979), pp. 80 and $95, \mathrm{n} .4$. Since $1979 \mathrm{~W}$. H. Scott and I have independently come to the same conclusion. This passage in the $S H Y C K$ is a major contribution to the history of the early Philippines. In 1011 the ruler of Butuan was identified in China by an Indian-style title and name: Śri "Pa-to-hsia-chih" (Śri Pad[uk]a Haji?), and his is the first recorded example of such a title in the Philippines. His envoys presented an engraved written memorial. No evidence is available that Mait (Ma-i) in Mindoro, trading with China at this time, sent a mission. Scott tells me that he intends to publish the SHYCK passage in full and relate its contents to what is now being excavated at the ancient Butuan trading site.

47. Wolters, "Note on the Capital of Śrivijaya," p. 230.

48. Sung-shih (Po-na edition), ch. 489, p. 23a.

49. Hirth and Rockhill, Chau Ju-kua, p. 59, n. 1, and p. 98, n. 1.

50. SHYCK, fan-i 4, p. 7738.

51. The eighteenth century historian, Ngô Thò' i Sĩ, applauded the new name but was dissatisfied that the Sung emperor did not call Vietnam "Nam-Viêtt"; Ngô Thò' i Sĩ, Việt-sũ' tiêu-ân (Saigon: Văn-hớa á-châu xuất-bãn, 1960), p. 154.

52. Wolters, "Chên-li-fu. A State on the Gulf of Siam at the Beginning of the 13th Century," Journal of the Siam Society, 48, 2 (1960), p. 18 in respect of Lo-hu, which sent missions in 1115 and 1155 and is probably Lopburi, and ibid., pp. 2-6, in respect of Chên-li-fu's missions in 1200, 1202, and 1205.

53. Wolters, Fall of Srivijaya in Malay History, p. 62. 
of Jambi and Palembang, nominal Javanese vassals, also sent missions to the Ming. and their overlord retaliated by sacking the Jambi capital in $1377 .{ }^{54}$

A brief review of the conduct of tributary missions in Sung and early Ming times suggests that the motives of the mission-sending Jambi rulers in the later eleventh and the twelfth centuries were a bid for high status in the eyes of the Sung court. In earlier times the Malay missions had been primarily for commercial purposes, but the Jambi rulers' privileged entrepôt trade was being corroded, and they would be anxious to protect the special relationship enjoyed by their Palembang predecessors in early Sung times. In 1017 the Palembang Mahãrāja, writing to the emperor, had described himself as "king of the ocean lands." 55 A Palembang mission came in 1028, the year when the Chinese court encouraged foreign traders to come to China. The mission arrived a few weeks after the court's decree, and the special marks of imperial favor conferred on the Malay ruler may reflect the court's pleasure. ${ }^{56}$ The next sequence of Malay missions came from Jambi in 1079, 57 1082, 1084, 1088, 1090, and 1094. The sudden spurt of diplomatic activity was not long after the capital had shifted to Jambi, and it is reasonable to suppose that the Jambi rulers wished to inherit the status enjoyed in China by those of Palembang. The intent of Jambi's last two missions to the Sung was clearly diplomatic. In 11561157 the mission resulted in the investiture of the ruler as "the king of San-fo-ch'i," and the emperor observed that he wanted "to praise the ruler for his sincerity and not for the sake of the local products his envoys brought." 58 The last mission was in 1178, when the ruler was given the insignia bestowed on his father in $1157 .{ }^{59}$

The Jambi missions can be explained as the rulers' endeavor to retain the reputation in China of being the maritime overlords of western Indonesia, in spite of changing economic circumstances. 1178, the year of Jambi's last mission, happens to be the year when Chou Ch'ü-fei described the force being used by Jambi to protect its entrepôt trade. The Jambi rulers were not, however, impoverished even though they were losing influence on the east coast of Sumatra. ${ }^{60}$ The Sung hui-

54. Ibid., ch. 5. Mckinnon tells me that a considerable amount of carbonized material was embedded in the mud below the high water line at Muara Kumpeh Hilir, and he suggests that the site was burnt. He wonders whether this happened when Majapahit sacked Muara Jambi in 1377.

55. For a discussion of this evidence, see Paul Pelliot, Notes on Marco Polo, 2 (Paris: Imprimerie Nationale, 1963), p. 839.

56. Wolters, "Note on the Capital of Śrivijaya," p. 227.

57. In 1079 San-fo-ch'i (Palembang) and Jambi sent missions; ibid., p. 232.

58. Ibid., p. 239, n. 86 .

59. Ibid., p. 234. The Sung-shih (Po-na edition, ch. 489, p. 15a) states that in 1178 the Chinese government decided that future missions were not to come to the capital, but remain in Ch'üan-chou. Today I would wish to modify what I wrote in "Note on the Capital of Śrivijaya," p. 238, about the commercial importance of Jambi in later Sung times. I had not yet realized the deleterious effect of overseas Chinese shipping on San-fo-ch'i's entrepôt.

60. Chao Ju-kua, writing in 1225, stated that Kumpeh, which I identify as Pulau Kumpeh north of Medan (Wolters, Fall of Śrivijaya, p. 43), was formerly a San-fo$c h$ 'i vassal but had gone to war and now had its own ruler; Hirth and Rockhill, Chau Ju-kua, p. 71. The name Kumpeh (Kam-p'ji) also appears in a pi-chi of 1206; Chao Yen-wei, Yün-lu man-ch'ao, Ts'ung-shu chi ch'êng collection (Shanghai: Shang-wu press, 1936), ch. 5, p. 152. The name is mentioned in a list of countries trading with Fujian. On Chao Yen-wei see Hervouet, Sung Bibliography, pp. 310-11. 
yao chi-kao records the tribute sent with the missions of $1156-1157$ and 1178 , and the items fill several columns of the text. The noteworthy feature is the variety, quality, and quantity of natural and manufactured products originally from countries in western Asia. In 1156-1157 no less than 81,680 katies of frankincense, for example, were shipped with the mission, while in 11783,009 katies of rosewater were sent. ${ }^{61}$ Even Chou Ch'ü-fei admitted that San-fo-ch'i was among the three most important entrepôts, and a pi-chi jotting gives a solitary but welcome glimpse of the fact that Jambi was attracting Chinese merchants in the later twelfth century. A Ch'üan-chou trader wanted to sail to San-fo-ch'i but was shipwrecked soon after he left China. ${ }^{62}$ Perhaps one day other jottings about voyages to the southern ocean will be found in pi-chi literature.

(A continuing link between Jambi and China in late Sung times is also suggested by an obscure piece of evidence recently recovered by archaeologists in Muara Jambi. A bronze gong was found in the precincts of Candi Kembar Batu with the following inscription indented with punchmarks. ${ }^{63}$

The fourth ${ }^{64}$ year of the Shao-ting reign-period [1231], the seventh month, the twenty-fourth [or twenty-eighth] day [= August 23, 1231, or August 27, 1231]. When the minister Hung was appointed to be in charge of the interior [of the imperial or of a provincial capital], he procured two large bronze gongs for the armory. [The last two characters 使 $\square$ are unintelligible.]

The inscription is crudely written, and its contents are baffling. I have been unable to identify a "Hung" whose duties in 1231 could have brought him into contact with someone from Jambi, and I am not certain that the bronze object was intended as a gift to the Jambi ruler. The object cannot even be assumed to have arrived in Sumatra in 1231 or soon afterwards. The discovery is interesting because it calls attention to Candi Kembar Batu. Further discoveries may help to explain why the bronze found its last home in Muara Jambi.)

I shall conclude with three pi-chi jottings about Java.

Su 0 , writing in the late ninth century, described the arrival of a Buddha-relic in the T'ang capital of Ch'ang-an in $873 .{ }^{65}$ The event was celebrated with magnifi-

61. The tribute on these two occasions is recorded in the SHYCK, fan-i 7, pp. 7863 and 7867. For a translation, see Grace Wong, "Place of Porcelain, "pp. 81-83. The SHYCK, fan-i 7, p. 7850, notes that, according to the Shan-t'ang $k^{\prime}$ ao so, San-fo$c h ' i$ presented tribute in the first lunar month of the second year of the $T$ 'ien-hsi reign-period (between January 20 and February 18, 1018). The types and quantities of the tribute are identical with those presented in 1157. Fortunately, the Chien-yên i-lai hsi-nien yao-lu (Chung-hua shu-chü edition, Peking, 1956, ch. 175, p. 2899) states that on February 6, 1157, San-fo-ch'i presented 80,000 "pints" of frankincense, swords, and many precious objects, and the variety and scale of the tribute are sufficient to verify the accuracy of the SHYCK's attribution of the mission to 1157.

62. Hung Mai (1123-1202), I-chien chih, Ts'ung-shu chi ch'êng collection (Shanghai: Shang-wu press, 1937), ch. 7, p. 52. Hervouet, Sung Bibliography, pp. 346-47.

63. I am grateful to Dra. Satyawati Suleiman for sending me a rubbing of the inscription.

64. The date of the year on the rubbing is $\square$. I am sure that the character was $\$$, or "four." The year in question would not be omitted from an otherwise exact date.

65. Su O, Tu-yang tsa-p'ien, p. 29. Su O, passim, records a considerable number 
cence. The emperor I-Tsung welcomed the relic when it reached the sanctuary of the Fêng-hsiang fa pagoda and presented it with the following gifts: a screen, ornamented with gold flowers; a couch made of "cooling" material (ivory or sandalwood?) ; a beautifully decorated mat for the couch; a "soft and warm" cushion; valuable incense; frankincense of fine resin. Su $O$ goes on to observe that these articles had been offered as tribute by $\mathrm{Ho}$-ling and were presented in the ninth year of the hsien-t'ung reign period $(860-873)$, which corresponds to 868 . The tribute was evidently regarded as worthy of display at an important Buddhist occasion.

Though different explanations have been proposed for restoring the toponym represented by Ho-ling, all who have so far written on the subject agree that the country in question was in Java. ${ }^{66}$ But Su O's use of the toponym creates a problem. The first notice of $\mathrm{Ho}$-ling in Chinese texts is as early as 640,67 and its last mission was in 818; thereafter, Javanese missions were registered under the name of Shê-p'o, or "Java," and they came in 820,831, and 839. ${ }^{68}$ The Hsin T'ang-shu states that there was another one in the 860-873 reign period, and this is probably the mission described by $\mathrm{Su} O$ as coming from Ho-ling in 868. Not much significance need be attached, however, to Su O's unexpected toponym. Su $O$ is unlikely to have had access to court records and was probably using a name familiar to T'ang Chinese and famous because it is mentioned in accounts of Chinese Buddhist pilgrims in the seventh and eighth centuries. The compilers of the Hsin T'ang-shu in the eleventh century certainly understood "Ho-ling" and "Shê-p'o" to be equivalent names, though this does not mean that the royal centers in question were identical.

Su O's jotting at least tells us that a Javanese mission arrived in China in 868 , which is in the reign of the Central Javanese ruler Kayuwangi/Lokapala whose dated inscriptions are from 860 to $882 .{ }^{69} 868$ is five years later than the Pereng inscription of 863 , which records the foundation of a Sivaite temple by the Rakai of Walaing, $\mathrm{Pu}$ Kumbhayoni. This person may have resigned his throne some years earlier. ${ }^{70}$ In $856 \mathrm{Pu}$ Kumbhayoni is supposed to have overthrown the Sailendra princely family in Central Java. ${ }^{71}$

The next jottings are from P'ang Yüan-ying's Wên-ch'ang tsa-lu and are notes taken by the author between 1082 and 1088 when he was responsible for receiving foreign envoys in the Northern Sung capital of K'ai-fêng. P'ang's entries begin in 1082. In the first chapter, written that year, he gives a list of countries known to the Chinese. ${ }^{72}$ Fifteen "southern" countries are mentioned, and they extend from

of foreign place-names which should be examined alongside the numerous ones in the Hsin T'ang-shu's account of the Pyu (HTS, Po-na edition, ch. 222 C, pp. 5b-6a).

66. I need mention only Paul Pelliot, "Deux itinéraires de Chine en Inde à la fin du Ville siècle," BEFEO, 4 (1904), pp. 279-95; L.-C. Damais, "Études sino-indonésiennes, III. La transcription chinoise Ho-ling comme désignation de Java," ibid., 52, 1 (1964), pp. 93-141.

67. Damais, "Études sino-indonésiennes, $111, "$ p. 131.

68. Ibid., p. 132.

69. L.-C. Damais, "Études d'épigraphie indonésienne. III. Liste des principales inscriptions datées de l'Indonésie," BEFEO, 46 (1952), pp. 32-43.

70. De Casparis, Prasasti Indonesia II, pp. 249-54.

71. De Casparis, "Dual Nature of Barabudur," p. 58.

72. P'ang Yüan-ying, Wên-ch'ang tsa-lu, Chung-kuo wên-hsüeh ts'an-k'ao tzŭ- 
Chiao-chih (Vietnam) to the Arab countries and the African Horn. ${ }^{73}$ In the same chapter he supplies five Chinese transcriptions of Javanese words for products. The same words appear in the Sung-shih's account of Java and are at the end of a general description of the country and preceding the recorded missions. In neither source is any indication given of the time when the transcriptions were first recorded, but Plang provides a terminus ad quem. ${ }^{74}$

P'ang Yüan-ying's transcriptions are as follows. The modern sounds of the words are enclosed in brackets. Pearls: muat $(\mathrm{mo})-t^{\prime} a\left(t^{\prime} o\right)-y a($ hia $)-1 a(10)$ = "mutiara." Elephant (ivory) : ka (chia) - liang (ling) = "gading." 75 Tortoise-shell:

liao ts'ung-shu edition (Shanghai: Chung-hua press, 1960), ch. 1, p. 3. On the author, see Hervouet, Sung Bibliography, pp. 191-92.

73. I follow Wheatley, "Geographical Notes on Some Commodities, " pp. 12-14, in identifying $T s^{\prime} e n g-t^{\prime} a n$ as the African Horn.

74. P'ang Yüan-ying, Wên-ch'ang tsa-lu, ch. 1, p. 11. On this matter see W. P. Groeneveldt, Notes on the Malay Archipelago and Malacca, Compiled from Chinese Sources (Batavia: Bruining, 1876), p. 17. Groeneveldt translates the Sung-shih's account of Java. The SHYCK, fan-i 7, p. 7856, states in a note that, according to the Sung-shih, a Javanese mission came in the 1068-1077 reign period. I have not found a reference to this mission in the Sung-shih. The note tells us that the Chinese were puzzled by two Javanese products. Wheatley discusses them in another and western Asian context and thinks that one of them may "possibly" be a bezoar stone and the other "probably" limonite; Wheatley, "Geographical Notes on Some Commodities," pp. 61, 75. On bezoar stones in Borneo, see I. H. Burkill, A Dictionary of the Economic Products of the Malay Peninsula, 2 vols. (London: Crown Agents for the Colonies, 1935), 1, p. 323.

75. The equivalence of the initial consonant in liang/ling and the retroflex $d$ in "gading" may offer a possibility for restoring the controversial Ho-ling toponym. though only if strong supporting geographical and archaeological evidence were available. Chao Yen-wei, an official in southern China whose work appeared in 1206, mentions Chia-ling among countries trading with Fujian; Chao Yen-wei, Yünlu man-ch'ao, ch. 5, p. 152. The character he uses for the first syllable is identical with that used by his near-contemporary. Chou Ch'ü-fei, to render the second syllable in "Mecca"; Ling-wai tai-ta, ch. 3, p. 2b. On the other hand, Damais, though conceding that the $\mathrm{Ho}^{-}$in Ho-ling occasionally represented $\mathrm{ka}$ - or ga-, doubted whether this was so in the case of Ho-ling and preferred to read it as haor wa-; Damais, "Études sino-indonésiennes. III," pp. 93-141 and especially pp. 108-21.

I take the opportunity of noting in passing that Chao Yen-wei also mentions four place names which resemble those associated with the Philippines (Ma-i, San-hsü, P'u-li-huan, and Pai-p'u-êrh); see Hirth and Rockhill, Chau Ju-kua, pp. 159-62. Chao begins his list with Po-ssŭ-lan, which seems to be an exact rendering of Basilan, an island off Mindanao and close to Zamboanga. Sung and later Chinese sherds have been found on the island; see map facing page 3 in Leandro and Cecilia Locsin, Oriental Ceramics Discovered in the Philippines (Rutland, Vt.: Tuttle, 1967). The reason why the identification has not been proposed is that Chao Ju-kua states that Po-ssü-lan was a dependency of Cambodia; Hirth and Rockhill, Chau Ju-kua, pp. 53-54. But Chou Ch'ü-fei in 1178 (Ling-wai tai-ta, ch. 2, p. 12a) does not include the name in his much shorter list of Cambodian vassals. Chao Ju-kua says that Pagan in Burma was a vassal, but not so Chou Ch'ü-fei. According to Chao Yen-wei, Po-ssü-lan and the other four places had kapok and cloth. Chao Ju-kua associates cotton products with his Philippine place names. 
$k a($ chia $)-l a(10)=$ "kara," for which, according to Pigeaud, ${ }^{76}$ "kura" is the better reading. Incense: $k^{\prime} u n-t u a n(t u n)-l u o(/ u)-m a=$ frankincense, for which the Sanskrit word is "kunduru." Rhinoceros horn: ti-miět (mi). I do not know what Javanese word was intended. (In Sanskrit, "timi" means huge fish. ${ }^{77}$ )

The final jotting is from Chou Mi's Kuei-hsin tsa-shih, written when the author was in retirement in $\mathrm{Hang}$-chou after $1276 .{ }^{78}$

Hsü Tzŭ-fang once obtained a Javanese bronze vessel. Its diameter was about four inches, and it was about three inches tall. It had a crossbeam like the support on a Chinese measuring container. Two images of the country's ruler and his wife sat on top [of the crossbeam]. A man was in attendance. [The man's] extreme ugliness resembled that of an actor [in China]. Two human heads were at his side. But I really did not know what use this thing had.

Chou Mi appears as mystified by this bronze vessel as Chu Yü had been on hearing the recitation of the "Peacock" sūtra. I suspect the object Chou Mi was trying to describe was a Javanese ritual incense burner. ${ }^{79}$ The two heads may be skulls and provide a clue for identifying the cult with which the censer was associated. Art historians will be able to comment on the jotting and perhaps spot a similar object in museum collections.

So much for the jottings I managed to extract from a few of the pi-chi brought to my notice by $\mathrm{Gu}$ Hai. Nothing of more than incidental interest has come to light. The jottings about Java are only collectors' items, and those concerning "Sriwijaya" can be assimilated to what is already known. My conviction grows that a useful outline of "Sriwijayan" history is now available, though we must always regret that it is not more substantial.

On the other hand, though I felt that I was looking for needles in haystacks. the same experience need not await others who search pi-chi for matters of interest to Indonesian historians. My intention in writing these notes has been to encourage $\mathrm{Gu} \mathrm{Hai}$ to persevere in preparing his bibliographical survey. Whatever he finds is likely to invite his readers to respond by supplying Indonesian contexts, and more extended ones than I have been able to provide, to illuminate his discoveries. What was translated long ago from the major Chinese sources needs to be reconsidered alongside information now available from other sources, but, by the same token, what turns up in the pi-chi also requires a review of relevant information from other sources. Gu Hai's project will help to maintain a useful exchange of ideas between sinologists and their colleagues, and early Indonesian history is bound to benefit.

76. T. G. T. Pigeaud, Java in the Fourteenth Century. A Study of Cultural History. The Nagarakertāgama, 5 vols. (The Hague: Nijhoff, 1960-63), 5, p. 177.

77. The transcriptions are contained in the glossary of Chinese characters at the end of this article.

78. Chou Mi (1232-1308), Kuei-hsin tsa-shih, Pai-pu ts'ung-shu chi ch'êng collection (Taipei : 1-wên press, 1966), p. 29b. See Hervouet, Sung Bibliography, p. 340 .

79. I was unable to identify a similar censer in the plates published by W. F. Stutterheim, "De Oudheden-Collectie Resink-Wilkens te Jogjakarta," Djawa, 14, 4-6 (1934), pp. 167-97. 


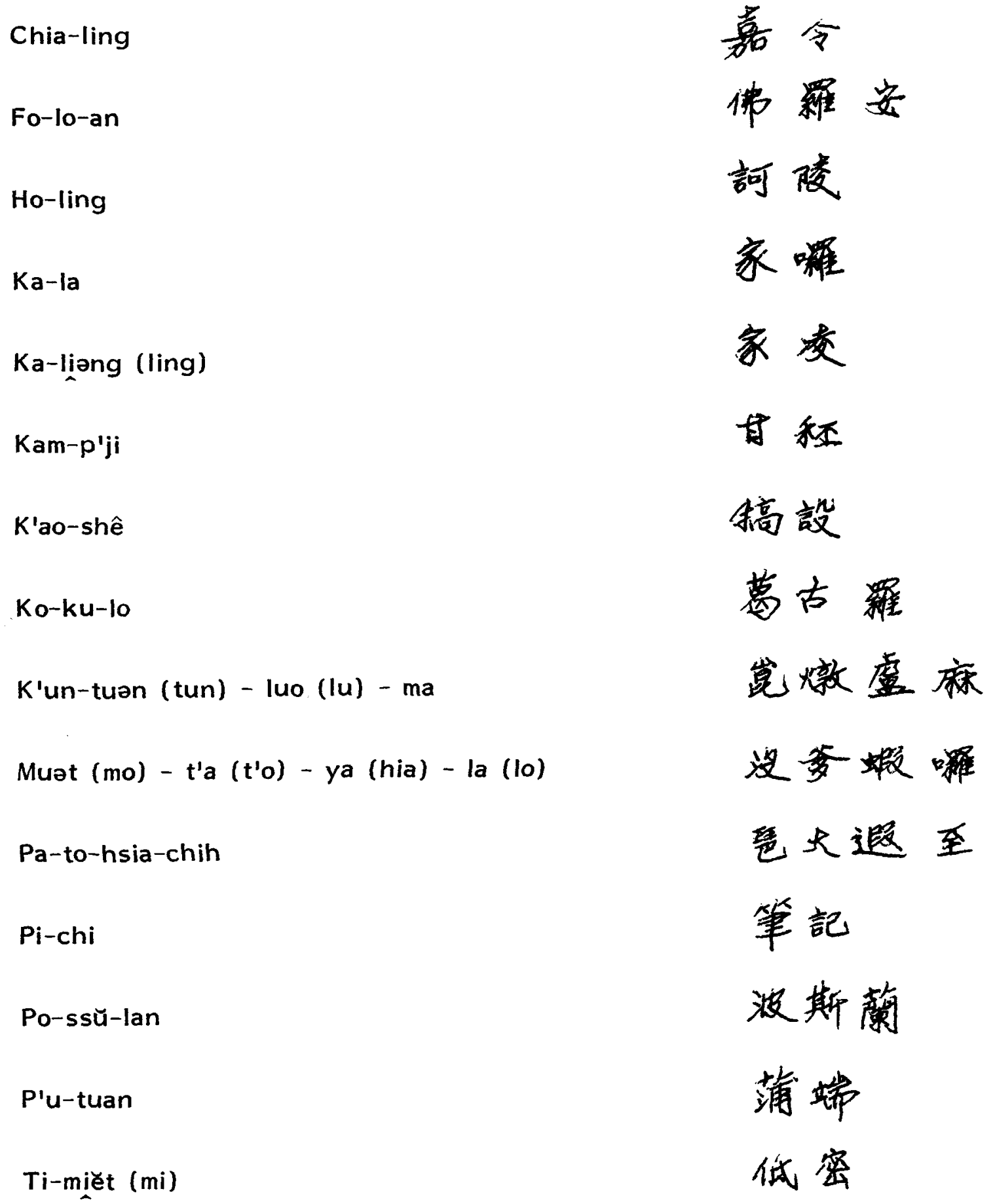

